\title{
STAKEHOLDERS PARTICIPATION FOR URBAN CLIMATE RESILIENCE: A CASE OF INFORMAL SETTLEMENTS REGULARIZATION IN KHULNA CITY, BANGLADESH
}

\author{
Sujit Kumar SIKDER*, Asad ASADZADEH*, Elias Danyi KUUSAANA*, \\ Bishawjit MALLICK**, Theo KOETTER* \\ * University of Bonn, ${ }^{* *}$ Karlsruhe Institute of Technology, Germany
}

\begin{abstract}
This study focuses on stakeholders' participation, perceptions and local contextualization in the Informal Settlement (IS) regularization processes in Khulna City. These processes are undertaken to address livelihood challenges of IS dwellers and to operationalize development initiatives in informal regularization projects. Adopting both a qualitative and quantitative approach, the research results show that IS formation in Khulna City started slowly with rural immigration. These immigrants remain vulnerable to climate change although some initiatives were undertaken since the last 20 years to improve their living conditions. The IS dwellers and local leaders initially participated in these settlement-upgrading initiatives due to accompanied incentives but they became adamant after the project period ended. It was also found that the city local government and NGOs do not have any permanent arrangement to sustain the IS regularization processes. The analysis of the interrelationships among the stakeholders revealed that the relevant public agencies are in conflict, and the role of the private sector is less recognized. The initiatives undertaken so far have limited success especially in granting tenure security, and the private landowners or local authorities that trespassed public spaces resort to forceful eviction. Amidst all these, there is the need for the formulation and implementation of climate resilience policies that address stakeholder participations in mitigating climate change consequences and enhance livelihood development.
\end{abstract}

Key Words: informal settlements, urban resilience, stakeholder participation, Bangladesh

\section{Introduction}

Rapid urbanization and population growth in hazard and risk-prone urban areas have jeopardized the sustainable development process in developing countries, and they contributed to the forming of one of the biggest urban challenges, differently called: informal, automobile, uncommon settlements; and the urban poor (Ravalion 2001). Most of these settlements are located in areas that are not deemed appropriate for residence (UN-Habitat 2003) while the residents have no legal claim to the land (Enemark and Mclaren 2008). Moreover, regardless of their growing numbers and exclusion from the main and formal parts of the city, inadequate building materials, lack of public urban services and institutions, poor transportation networks, inappropriate power lines, inadequate hospitals, fire or police stations and poor sanitation have pre-disposed the vulnerability of the urban poor to climate change related disasters (Dodman and Satterthwaite 2008, Feiden 2011). According to Bosher et al. (2007), the severity of climate change in these settlements is related to poverty (low access to assets), marginalization (poor access to public facilities) and powerlessness (low access to political and social networks).

Nevertheless, the vulnerability of such communities to climate change is not simplified by focusing on their location and characteristics, but also by how they are managed, serviced and more importantly, to what extent communities and local organizations are capable to cope with climate change (Laukkonen et al. 2009). This is because the damages caused by climate 
related disasters should not only be seen as natural events, but also as a failure of the urban management and institutions. Hence, there is a vigorous ongoing debate to demonstrate different ways to integrate climate risk and resilience in the informal settlements planning. For instance, Comfort (1999) emphasises collective learning and she argues that linking information technology and organizational learning presents an opportunity for the communities to be more resilient against shared risks. Therefore, by relying on institutional and community capacity dimensions in enhancing climate resilience, this paper intends to explore the dynamics of the stakeholders' participation in managing informal settlements; and the relevance of stakeholders' participation in informal settlements' regularization in the light of the emerging debates around building resilient cities.

Following the above introduction, the next section of the paper will review the literature on informal settlements and climate resilience. A brief overview on the informal settlement situation in Bangladesh is discussed in section three. The fourth section presents the study methodology and it is followed by section five which presents an empirical case study on Khulna city. The conclusion is presented in section six.

\section{Informal Settlement (IS) and Climate Resilience}

United Nations estimate that at least 900 million urban dwellers in low and middle-income countries live in poverty (UN-Habitat 2003) and $60 \%$ of the urban population by 2030 will fall into this social class (Cohen 2004). Over urbanization and the rapidly expanding urban informal settlements in developing countries will continue to face severe climate risks in the light of climate change (Tanner et al. 2009). Although Hardoy et al. (2001) argue that the concentration of people and enterprises also provides many opportunities including economies of scale, proximity or agglomeration of infrastructures to reduce risk, there are undeniable linkages between urban poverty and the vulnerability level to climate change. According to IPCC (2008) the poorest people in the least developed countries have lesser capacity to adapt and tolerate many effects of climate change. These effects are also widespread, interconnected and cumulative.

However, there is growing integration to address climate change risks by focusing on climate change adaptation and resilience (Jabeen et al. 2010). Climate change resilience is the capacity of an individual, community, or institution to dynamically and effectively respond to shifting climate impact circumstances while continuing to function at an acceptable level (Rockefeller Foundation 2014). The terms of capacity and adaption have become important issues in the international and domestic discussion on climate change resilience. Numerous definitions of adaptation are found in climate change resilience literature, mostly denoting on a common theme. Brooks (2003: 38) describes adaptation as "adjustments in a system's behaviour and characteristics that enhance its ability to cope with external stress". In the context of climate change, Smit et al. (2000: 225) refer to adaptation as "adjustments in ecological-socioeconomic systems in response to actual or expected climatic stimuli, their effects or impacts". Satterthwaite (2007: 5) has tried to relate this definition to the urban scale, thus describing adaptive capacity as "the inherent capacity of a system, population or individual/household to undertake actions that can help avoid loss and speed recovery from any impact of climate change". To attain climate resilient cities, Jabeen et al. (2010: 430) emphasized that stakeholders should distinguish between "spontaneous" and "planned" adaptation. Planned adaptation is referenced to deal with hazards and to allow the local governments, stakeholders and planners to draw on scientific knowledge in order to map and to predict climate risks.

The central discussions on urban resilience focus on understanding the local response to climate change in the era of good governance and institutional approaches. Urban resilience applies to the social-institutional system, urban infrastructure and energy systems in urban areas (Aylett 2014). Therefore, there is the need to increase the ability of urban systems to 
drive active stakeholders' collaborations along with innovations and new ideas. Notwithstanding the exposure to extreme unfavourable climatic conditions in urban informal settlements, about 1 billion people of the world's urban populations live in slums and the majority of them in the developing world. In addition, it is projected that in the next fifty years, two-thirds of the humanity will be living in towns and cities and a large part of this growth will take place in the form of informal settlements. This explains why the United Nations MDG-7 target 11 aimed to achieve a significant improvement in the lives of 100 million slum dwellers by 2010 through sustainable approaches on the complexity of informal urbanization. However, even if the MDG 7 target 11 is achieved, the figure falls much below the population already living in informal settlements across the globe. Additionally, environmental degradation increases the people's mobility to cities and it contributes to intensifying the vulnerability of the victims (Renaud 2012, Resilience Alliance 2007). These poor people who are forced to migrate from the rural areas generally settle in the poorest and often most exposed neighbourhoods (i.e. informal settlements) in large cities (Aylett 2014, Revell 2010). UNFCCC was initiated to develop the adaptive capacity of poor people since the severe problems that emerged under climate change obviously made the poor people of the society more vulnerable (Oliver-Smith 2009). Therefore, the momentum for pragmatic changes may be realized by changing the situation at different levels in urban management as well. Warner (2010) contended that the current structures and organizations would not be enough to cope with the excessive immigration flows to the cities. Moreover, such human mobility due to climate change could become an issue for regional security. Hence, new modes of governance are needed to bridge the gaps in the protection and assistance of climate change migrants.

However, there are varied opinions about how to improve the situation as the number of informal settlers grows. According to Durand-Lasserve (1996) there will be 1.5 billion informal settlers by 2020 and hence they view the MDG-7 target as extremely inadequate. Besides, overall donor financing for achieving the MDG-7 target is very low. Hence, the UN and some partner agencies reported that the best way to address climate change impacts on the poor in suburban settlements is by integrating adaptation responses into development planning (World Bank 2010). There have been some attempts to identify the link between environmental change and migration (Mallick et al. 2011) as well as numerous studies (Warner 2010, Valkering et al. 2005) advanced to explore the stakeholders' behaviour. However, most of these studies did not focus on the urban informal settlements directly. Therefore, this paper contributes to the missing link between urban informal settlements and climate change and it shows how climate resilient cities can be promoted through enhancing the adaptive capacity of the urban poor at local scale.

\section{The situation of Informal Settlements in Bangladesh}

Bangladesh is already overwhelmed with many problems relating to high population density (953 per sq. km), land scarcity, human health and illiteracy (World Bank 2010). Consequently, informal urbanization has become a common phenomenon like other third world countries. About 5.5 million people are living in slum and informal settlements (Angeles et al. 2009). Tackling this situation has not yet adequately evolved due to inadequacies in the legal, institutional, economic and technical capabilities. Besides, Bangladesh is regarded as the most vulnerable country of the world in relation to climate change (IPCC 2008). Due to this, Bangladesh may see mass movements of people from the flood-prone areas to urban centres in search of non-agricultural jobs. For example, the worsening environmental situation in the Ganges delta could render migration as one of the most realistic options available for some Bangladeshi people (Warner et al. 2009).

There are two major factors that allow for the informal settlements development - a) the weakness of the statutory planning processes, and b) strong rural-urban migration (Vincent 2009). Roy and Abdullah (2005) have confirmed that the development of informal settlements 
in Bangladesh is a consequence of migration. On their arrival in the urban areas, the poor migrants routinely turn to slums and squatter the settlements for affordable shelter. At present, approximately $35 \%$ of the population of the six major divisional cities lived in slum settlements, though they did so on only $4 \%$ of the land area of those cities. The total slum population across the cities was over 5.4 million as of 2006 (Angeles et al. 2009). About more than $90 \%$ of these settlements in different cities of Bangladesh are located on government and private land. Thereby living in these deprived neighbourhoods contributes to the social exclusion of the dwellers (Begum and Moinuddin 2010).

Considering how important it is to tackle the challenges of informal urban settlements, there have been several initiatives by the public sector for the informal settlement improvement since the 1980s (Siddique et al. 2002). However, most of these slum improvement initiatives were short-lived and with marginal impacts. The few projects that seemed to have recorded some impressive successful results begin to disappear at the end of the implementation periods. Patel (2013) argued that successful outcomes of formal changes are possible only if informal continuities (continuation of the power and influence of the local community development committee) after the project periods are established. Urban poor communities are still facing insecurity of land tenure, threat to eviction and inadequate services. Evictions have always characterised the urban management history of Bangladesh. The most recent massive eviction took place at the Korail slum in Dhaka, which was home to several thousands of people for over nearly two decades. According to the news report of the Daily Star (29 th July 2009$)$, the basic service infrastructures, under the provision of different NGOs and donor-supported programmes, were also demolished. This action was taken by two public agencies - the Bangladesh Telecommunication Company Limited (BTCL) and the Department of Public works, who owned these lands. These evictions were administered under the Ministries of Public Works as well as Science and Information Technology to free their lands from squatters (Alam and Akter 2012). These actions created an acute humanitarian crisis followed by massive demonstrations of by such homeless people. Finally, they created public sufferings and insecurity in the whole capital city. However, the divisional cities are now facing these kinds of problems due to the huge population displacement as a consequence of extreme event and climatic change consequences like cyclones and salinity (Mallick et al. 2011). This situation is also prominent in the coastal cities. In our view, there is a need to identify the critical actors, networks, agencies and institutional roles to address these problems within a practicable framework. Therefore, it is necessary to find out how to manage informal settlements with the active participation of the different actors and/or stakeholders in a coastal city like Khulna.

\section{Methodology}

\section{Study area}

The coastal zone of Bangladesh is generally perceived to be a zone of multiple vulnerabilities. The government of Bangladesh has already identified the coastal zone as "vulnerable to adverse ecological processes" and as one of the three "neglected regions" (Mallick et al. 2011). Moreover, it is reported that Khulna is one of the vulnerable coastal cities prone to climate change risks (CLACC 2009). Khulna is the third largest city in Bangladesh and it has been known as an industrial city with a population of more than one million inhabitants. It has experienced an extremely rapid urbanization during the 1950 s and 1960 s due to industrial expansion and rural-urban migration. The recent statistics indicate that about $19.5 \%$ of the urban population is living in slums and informal settlements, while 538 clusters have been identified all over Khulna city alone (Fig. 1). Since the industrial growth of the early '60s, informal settlements of Khulna remain as a popular home for strange immigrants (Murtaza 2000). These huge numbers of urban citizens are living in very miserable conditions with limited basic services and threatened tenure security. Meanwhile Khulna city has benefited to some extent from all the public and private sector initiatives for the informal settlements 
improvement so far undertaken in several urban areas in Bangladesh. Yet, it is a matter of concern that most of these settlement improvement initiatives have insignificant progress for providing sustainable tenure security for the urban community. It is assumed that the initiatives are undertaken on a temporary basis without the consideration of stakeholders' participation. It is necessary to find out how informal settlers can get better tenure security through the active participation of different actors and stakeholders in the regularization process. The momentum for change may be realized by changing the situation at different levels in the urban governance structure. Therefore, by considering the location dynamics, the objectives and research goal, Khulna city will be a potential case study area for better research outcomes.

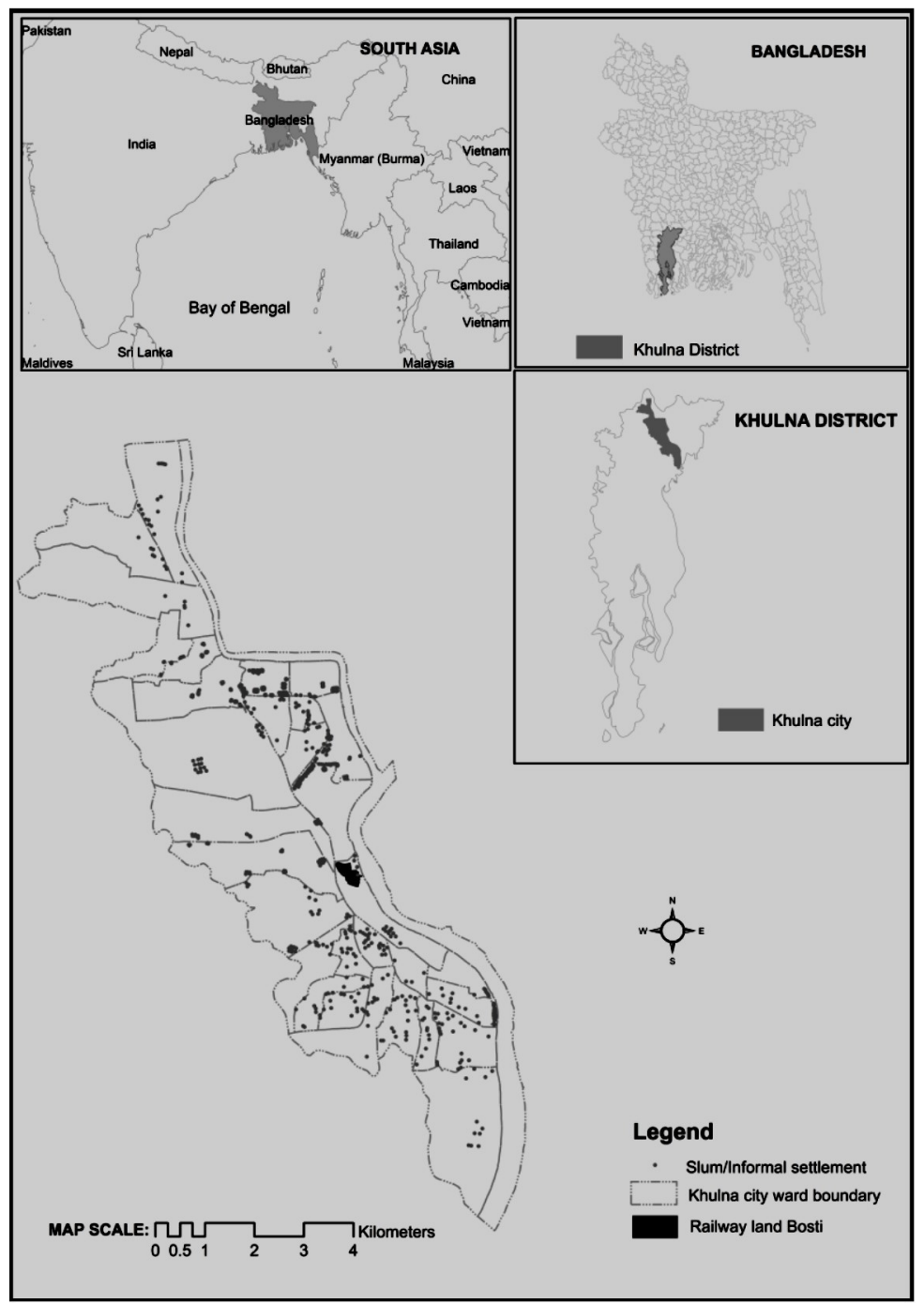

Fig. 1 - Location of Khulna city and Bosti railway land

Source: ESRI world dataset, Khulna Development Authority (2001) 


\section{Informal settlements assessment}

The study adopted a case base approach. At this point, a representative informal settlement was identified within Khulna city by formulating a set of pre-defined criteria. These criteria included land occupancy, the existence of improvement initiatives and significance in terms of population size, location and area (Table 1). After gathering all secondary information available on informal settlement clusters of Khulna city, we performed a preliminary desk based investigation and we also discussed with the local experts. As a result, the Bosti Railway land near Joragate was found relatively relevant as a case study. The area is located near the Central Business District (CBD) under the jurisdiction of Khulna city corporation ward Number 21. It is also known as 5 Number Ghat Bosti, Joraget Bosti (Fig. 2).

\section{Pre-defined criteria and their significance on Bosti Railway land}

Table 1

\begin{tabular}{|l|l|}
\hline \multicolumn{1}{|c|}{ Pre-defined criteria } & \multicolumn{1}{c|}{ Criteria significance } \\
\hline $\begin{array}{l}\text { 1. The cluster settlement should be located } \\
\text { on the illegally occupied public land. }\end{array}$ & $\begin{array}{l}\text { 1. The land belongs to the Bangladesh } \\
\text { railway authority (public authority) and it is } \\
\text { illegally occupied. }\end{array}$ \\
\hline $\begin{array}{l}\text { 2. There should have some involvement of } \\
\text { the public and I or private sector for } \\
\text { improvement initiatives. }\end{array}$ & $\begin{array}{l}\text { 2. Past/ongoing improvement initiatives of } \\
\text { LGED-UPPR (Public sector initiative), } \\
\text { Nabolok-EECHO (Private sector initiatives). }\end{array}$ \\
\hline $\begin{array}{l}\text { 3. It should be significant in terms of size of } \\
\text { population, location, total area within all } \\
\text { other competitive clusters. }\end{array}$ & $\begin{array}{l}\text { 3. Located nearby CBD, BIWTA Ghat, } \\
\text { along the growth axis, 1 148 households, } \\
\text { higher land value and densely populated. }\end{array}$ \\
\hline
\end{tabular}

Source: Authors 2013

Overview of survey tools, respondents and data sources

\begin{tabular}{|c|c|c|c|}
\hline $\begin{array}{l}\text { Survey } \\
\text { Method }\end{array}$ & $\begin{array}{l}\text { Type of respondents } \\
\text { and organizations }\end{array}$ & $\begin{array}{l}\text { Informal settlement/ } \\
\text { Key respondents }\end{array}$ & Goals and objectives \\
\hline $\begin{array}{l}\text { HH survey } \\
(88)\end{array}$ & $\begin{array}{l}\text { Informal settlement } \\
\text { dwellers }\end{array}$ & Bosti Railway land & $\begin{array}{l}\text { Settlers' origin, land } \\
\text { occupancy, socio- } \\
\text { economic conditions, } \\
\text { urban services, } \\
\text { movement dynamics, } \\
\text { participation, tenure } \\
\text { security }\end{array}$ \\
\hline \multirow{6}{*}{$\begin{array}{l}\text { Key Infor- } \\
\text { mant Inter- } \\
\text { view (6) }\end{array}$} & Municipal corporation & $\begin{array}{l}\text { Chief town planner, } \\
\text { KCC }\end{array}$ & \multirow{6}{*}{$\begin{array}{l}\text { Initiatives so far, future } \\
\text { plan, stakeholder } \\
\text { participations, power } \\
\text { relations, attitudes to the } \\
\text { others, local dynamics, } \\
\text { project experiences and } \\
\text { suggestions }\end{array}$} \\
\hline & $\begin{array}{l}\text { City development } \\
\text { authority }\end{array}$ & $\begin{array}{l}\text { Chief planning officer, } \\
\text { KDA }\end{array}$ & \\
\hline & Public land owner & $\begin{array}{l}\text { Property development } \\
\text { officer, BRA }\end{array}$ & \\
\hline & Public sector initiator & $\begin{array}{l}\text { Town manager, UPPR } \\
\text { Project }\end{array}$ & \\
\hline & $\begin{array}{l}\text { Private (e.g. NGO) } \\
\text { initiator }\end{array}$ & $\begin{array}{l}\text { Programme manager, } \\
\text { Nabolok NGO }\end{array}$ & \\
\hline & $\begin{array}{l}\text { Local elected repre- } \\
\text { sentative }\end{array}$ & $\begin{array}{l}\text { KCC Ward-21 } \\
\text { Councillor }\end{array}$ & \\
\hline
\end{tabular}

Source: Authors 2013 


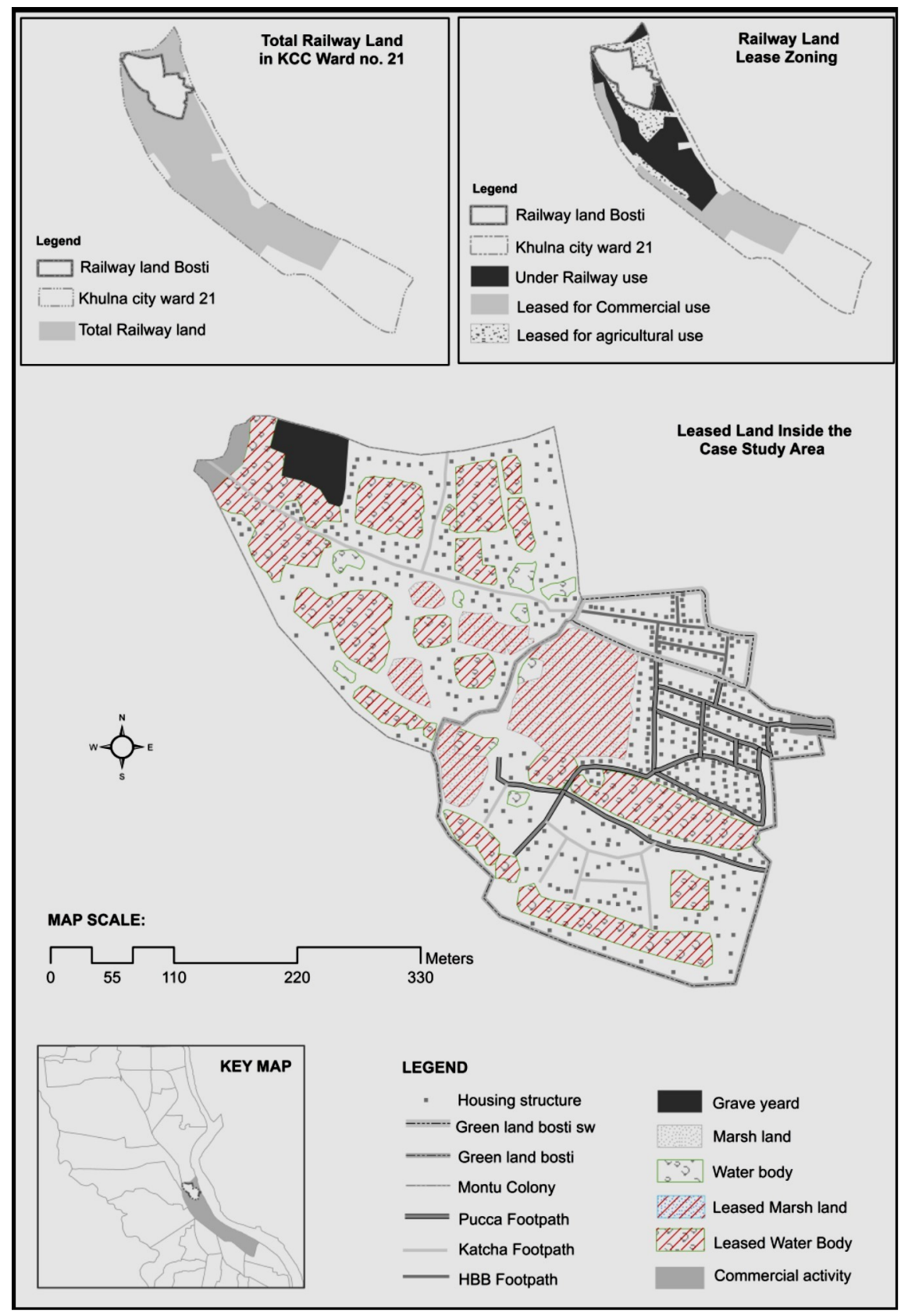

Fig. 2 - Detailed land use, housing structure in railway land Bosti and surroundings Source: Authors 2013, Khulna Development Authority (2001), CUS (2005) 
The settlement has an area of 21.67 acres and it is home to about 1148 urban poor households. Depending on different individual characteristics, the whole settlement can be divided into three parts - 1) Montu Colony, 2) Greenland Bosti, and 3) Sweeper Colony. The whole settlement formation process took about 100 years and it is still ongoing at different scales. It is evident that the Montu Colony settlement formation process had started in an unorganized way and it followed a slow progression. At the second and third part it became organized, and fast, due to support from different actors against the eviction actions of the railway authority.

Adopting both qualitative and quantitative approaches, semi-structured questionnaires and interview guides were used to collect data for the study. In total, eighty-eight (88) randomly selected informal settlers were interviewed using the semi-structured questionnaire. Six (6) key informant interviews were also conducted with institutional representatives and civil society representatives (Table 2).

\section{Analytical tools}

After raw data collection, both primary and secondary data were compiled manually. The descriptive opinions from key informants and unstructured materials from interviews, observation and other records were coded systematically for analysing the existing stories of the informal settlements regularization initiatives and mapping the stakeholder participation. The stakeholder mapping has partially followed the guidelines described in the stakeholdermapping manual of Morris and Baddache (2012). The stakeholders were identified, analysed and mapped with the resulted facts and related codes that were extracted from the key informant interviews and published sources. The computer software packages: SPSS (Statistical Package for Social Sciences), Photoshop, ERDAS IMAGINE and ArcGIS were employed for household survey data analysis and visualizing physical status of the case study area.

\section{Results and Discussion}

\section{Settlers' socio-economic condition: vulnerable and dependent}

Lower incomes (54\% less than 4000 BDT), higher expenditures (51\% more than 4000 BDT), unsecured occupation and lack of land tenure security are major characteristics of the informal settlers' standard of living in the Bosti Railway land. From our informal settlers' interviews, informal settlers mostly migrated from the rural areas due to pushing factors such as unemployment $(40 \%)$, landlessness $(39 \%)$ and disaster events $(21 \%)$. They occupy the public land because they access the land almost without any payments and middlemen supports. Since these occupations are unauthorized and not legally certified, informal settlements are prone to tenure insecurity. Under such unsecured tenure conditions, informal settlers $(36 \%)$ have faced several threats of eviction incidents but they always return to the same place since they do not have other options. These settlers depend on the local political leaders for legitimacy and to secure their vulnerable land tenure. Consequently, they are not free to express their own opinions and to participate actively in the decision-making process. They hence become an isolated urban entity separated from the mainstream urban population. The study argues that the higher the socio-economic vulnerability of informal settlers, the more they are compelled to live at the mercy of local politicians and elites for protection. In our view this practice does not allow informal settlers to be self-confident and free from the vicious cycle of poverty. In addition, the formal planning system does not allow informal settlements to get any planned and legitimate supply of urban services although informal settlers are also formally recognized as part of the urban enclave. This may also explain why informal settlements are often associated with the illegal connection to public mains for water and electricity. This opens them up to further risks of water pollution and fire outbreaks. 


\section{Physical condition: poor and limited}

From the field data, there is an ongoing demand for improvement of the physical conditions of urban settlements in Bangladesh. The basic urban services and facilities - water supply, toilet facilities, drainage and footpaths are partially provided through individual initiatives, and some few public and private sector initiatives. Most often, these services are over loaded due to the large amount of users (e.g. 15-20 households share per tube well and toilet). Consequently, these infrastructures collapse very fast and yet settlers cannot renovate or maintain them due to their endemic financial and technical limitations. During the rainy season, flooding is a common phenomenon and informal settlers have to face miserable circumstances. This also explains why the sustainability of physical improvement projects in informal settlements always comes under question after the end of the project period. The study found that the poor physical conditions of informal settlements are not only a problem for the informal settlements; it also has an adverse effect on the surroundings of the urban environment and it poses a dire public health risk. Fig. 3 and Fig. 4 below labelled are used to depict some of the deplorable conditions and indecent urban exposures that not only pose health risks to the immediate informal environment, but can become a source of serious health threat to urban lives as well.

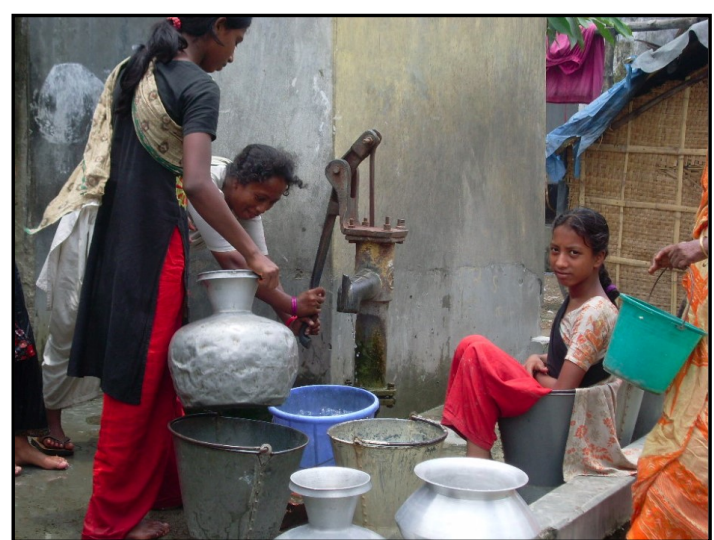

Fig. 3 - Tubewell installed by LPUPAP project; Location: Greeland Bosti, Khulna city

Source: Authors, September 2013

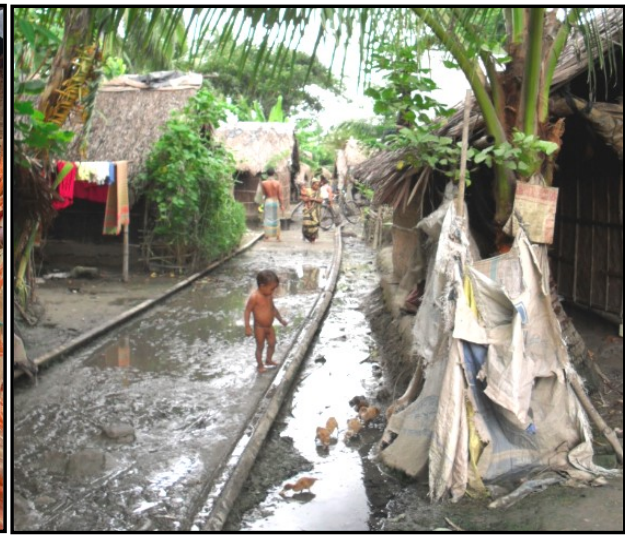

Fig. 4 - Poor conditions of access road; Location: Montu Colony, Khulna city

Source: Authors, September 2013

\section{Stakeholder identification}

There are two types of stakeholders that are involved in the process of informal settlement upgrading and regularization. Following the UN-Habitat guidelines for pro-poor land management, the local stakeholders in the Bangladesh case study are identified in Table 3.

The key public sector stakeholders like Khulna City Corporation (KCC) have no updated database on informal settlement and direct improvement initiatives. In our view, the KCC only provides some indirect support to informal settlements in order to gain political capital. The Khulna Development Authority (KDA) is not involved in upgrading or regularization processes but it believes that the responsibility should be taken by the municipality and the concerned landowners. 
List of stakeholders

\begin{tabular}{|l|l|}
\hline \multicolumn{2}{|l|}{ A. Primary Stakeholders } \\
\hline $\begin{array}{l}\text { 1. Informal } \\
\text { Settlement Dwellers }\end{array}$ & $\begin{array}{l}\text { Those who are living in informal settlements with many fold } \\
\text { informality }\end{array}$ \\
\hline 2. Land Owners & $\begin{array}{l}\text { Agencies or individuals hold the legal land rights, where informal } \\
\text { settlements take place (i.e. Bangladesh Railway Authority) }\end{array}$ \\
\hline $\begin{array}{l}\text { 3. Municipal Local } \\
\text { Governments }\end{array}$ & $\begin{array}{l}\text { Agencies responsible for city administration, basic services } \\
\text { provision, urban development planning and management (i.e. } \\
\text { Khulna City Corporation). }\end{array}$ \\
\hline $\begin{array}{l}\text { 4.Regional Develop- } \\
\text { ment Agencies }\end{array}$ & $\begin{array}{l}\text { Agencies responsible for planning as well as development control } \\
\text { (i.e. Khulna District Assembly). }\end{array}$ \\
\hline $\begin{array}{l}\text { 5. Local Elected } \\
\text { Representatives }\end{array}$ & $\begin{array}{l}\text { The elected representatives by the public voting process (i.e. Ward } \\
\text { Councillor). }\end{array}$ \\
\hline B. Secondary Stakeholder \\
\hline 1. Working NGOs & The indivisible part of any type of development as a private sector. \\
\hline $\begin{array}{l}\text { 2.The Public } \\
\text { Agencies under } \\
\text { Central Government }\end{array}$ & $\begin{array}{l}\text { The responsible government departments that have no direct } \\
\text { interest in informal settlement regularization process but they have } \\
\text { indirect roles for facilitating the whole process. }\end{array}$ \\
\hline 3. Local Politician & $\begin{array}{l}\text { Leaders of different parties and their followers who take informal } \\
\text { settlement as a political agenda during the crisis period. }\end{array}$ \\
\hline 4. Local Elites & $\begin{array}{l}\text { Those are getting indirect benefits by providing some illegal or } \\
\text { informal services i.e. electricity; and also benefiting through social } \\
\text { crimes i.e. drag trading. }\end{array}$ \\
\hline 5. Donor & $\begin{array}{l}\text { Agencies that are providing funds and technical support i.e. UN } \\
\text { agencies, DFID. }\end{array}$ \\
\hline
\end{tabular}

Source: Authors, (2013) and UN-Habitat, (2003)

It was observed that the public sector agencies could influence and support the regularization process for the informal settlements because of their rich local experiences and expertise. The public (e.g. Urban Partnership for Poverty Reduction) and private sector (e.g. Enhancing Environmental Health by Community Organizations) project teams only update their database concerning their specific project sites but not the general information on all informal settlements. They have better connection with the informal communities and donor agencies. These private and public sector stakeholders also coordinate well with one another to avoid functional overlaps. The private sector capacity to make valuable impact in informal settlement upgrading is higher than the public sector because they are free to make their own decisions.

The landowner (i.e. Bangladesh Railway Authority) considers the informal occupancy of informal settlers as temporary squatting. Therefore they do not maintain any database and they have no legal provision or interest to work in the favour of informal settlers. On the contrary, they initiate eviction measures to clear their land from illegal occupancy and want to lease the land for commercial or agricultural purposes. They have the possibility to share or lease their additional vacant land with the settlers or development agencies. The local leader (i.e. Ward Councillor) plays an important role due to the persistence in their local political interests. The local councillor maintains updated information on informal households in the informal settlements, installs infrastructures from his personal budgetary allocations, and leads protests against forced evictions. The local leaders have the potential to smoothen the way forward due to the structure of local power and better linkage with essential public-private sector actors. The 
settlers mostly participate in community groups and also take initiatives for land filling and maintenance of infrastructures. Among other stakeholders, the private sector agency faced intense difficulties at earlier stages to motivate the settlers to participate in different regularization initiatives. The settlers however feel stressed and they lack confidence due to tenure insecurity and frequent threats of eviction. The majority of informal settlements are highly dependent on the local political (Ward Councillor) leaders for their future improvement.

\section{Stakeholders mapping}

Stakeholder mapping (Fig. 5) is a strategic tool that identifies and assesses the effectiveness of the different individuals or group of stakeholders to solve a particular problem area (Morris and Baddache 2012). It examines the stakeholder's power, level of interest and internal relationship among them.

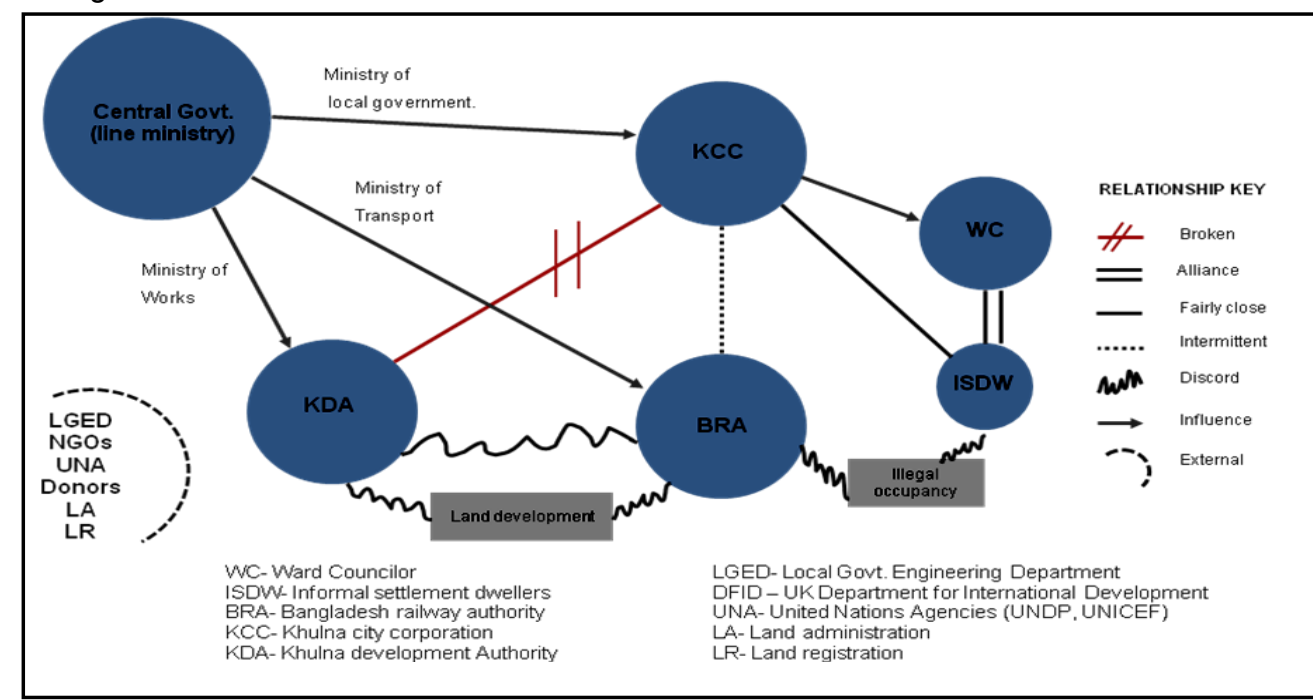

Fig. 5 - Stakeholder map to regularize the Railway land Bosti

Source: Authors own Illustration with field survey data (2013)

by following Morris and Baddache (2012)

The Khulna Development Authority and Khulna City Councillor have a broken relationship between them. They blame each other and compete for supremacy. They have no common platform for co-ordination and co-operations for regularising informal settlements and urban development in general.

The Khulna Development Authority has a discordant relation with the BRA authority regarding the land development issue. The Bangladesh Railway Authority officials confirmed that the Khulna Development Authority unnecessarily delays when they ask for land use clearance certificates for the new railway station construction project.

The Khulna City Councillor and Bangladesh Railway Authority related intermittently as they have some ongoing negotiations regarding local taxations, informal occupations, commercial activities and urban basic service provisions.

Consequently, the informal settlement dwellers and Ward Councillor are in an alliance for a better future. Mutual benefits are the major motivations - because informal settlers need 
political shelter, similarly, the Ward Councillor need continuous public support to retain political power and legitimacy.

Lastly, the Khulna Development Authority does not have any kind of connection with the informal settlers although the informal settlements on the Bangladesh Railway Authority land are located just opposite to Khulna Development Authority administrative building.

\section{Position of key stakeholders}

The current position of stakeholders in informal settlement improvement projects depends on their level of participation in the project. This is because the stakeholder participation in informal land management can vary from passive dissemination of information to active engagement in decision-making. It can be very varied depending on the local context (Masum 2009, United Nations 2009). In the case of our studied informal settlement, the Urban Partnership for Poverty Reduction (UPPR) project team and NGO-Nabolok, somehow, reached partnership at the level of citizen-power according to the project documents. It is however evident that the partnership is working properly in very few cases. For instance, the Municipality (i.e. Khulna City Corporation) shows negative attitudes to the private sectors' activities (i.e. NGO-Nabolok). In addition, both of these stakeholders are temporary workers on short-term projects. Their participation will not be sustained in the future if the other related conditions such as elected political leadership and donor supports change. In addition, it is needful to know that the administrative activities of public sector initiatives (e.g. UPPR) are somehow bypassing the mainstreams of local public agencies like Khulna Development Authority and Khulna City Corporation. They want to formalize the Community Based Organizations (CBOs) with better capacity, voice and negotiation powers.

The study found that the Khulna Municipality, Ward Councillors and informal settlers' positions are also varied within the second level of participation and it is more of placation, consultation and information. It mostly depends on the targeted informal settlement clusters because the Municipal Authority and local leaders are mindful of their maximum political benefits. All informal settlers do not have equal capacity to participate in the regularization process. Development authorities, landowners, and other related public-private agencies somehow remain in the lower part of the participation ladder. Their level of participation is less supportive and they rather put obstacles within the improvement process.

\section{Regularization process: Limited focus on land tenure security}

It has been found that the initiatives undertaken so far by both the public and private sector for improving the condition of informal settlements in Khulna city have somehow ignored the land tenure security. They mostly focus on physical improvement as a part of improving the upgrading mechanism. Consequently, at the end of the day all efforts of physical improvement become zero since the tenure of their stay itself is insecure and there is no sustainable solution to the vulnerable socio-economic and poor physical condition of the settlements. For instance, after the installation of basic infrastructures, there is still a chance for the authority or landowner to enforce eviction measures if there are no pre-ensured means of creating land tenure security. In our view the regularization of informal settlements is more appropriate and effective on the basis of assured tenure security compared to just an upgrading process. However, political factors, poor roles of stakeholder participation and limited awareness among the settlers are major barriers. The political interest is geared in favour of upgrading processes as the infrastructure installation takes less time and it is more visible to win political capital especially in the election years.

The poor stakeholder participation in informal settlement upgrading or regularization process is 
simply a part of the limitedness of participation in most development practices in the developing countries. The practice of participatory development is limited in Bangladesh and without participatory development it would be difficult to convince stakeholders for re-development and guided development (Roy and Sowgat 2005). The research presents that the informal settlement improvement process in Khulna city is non-effective due to poor stakeholder participation in the regularization process.

The key stakeholders such as the Municipal government have no legal provision, administrative section and funding for informal settlement improvement. The Regional Planning and Development Agencies are also somehow avoiding the preparations of land use plans for informal settlements. The spatial development plans seldom include schemes to improve the condition of the urban poor and these plans are never implemented. The KDA is also very reluctant to support any kind of public and private sector initiatives that do not promise any direct benefit. The private sector participation is also very limited due to limited resources and political support. Moreover, the landowners are not properly involved within the improvement process. The land administration and registration department have no involvement at all like other related public and private agencies.

\section{Conclusion}

The comprehensive and sustainable solutions for informal settlements must take account of both local contexts and include ways to mobilize the resources available at the local level. The regularization initiatives through efficient stakeholder participation will help to realize the urban climate resilience propositions (e.g. transformation, adaptation and implementation). The solutions of emerging urban problems must be part of the broader urban and national development strategies supported by relevant institutional and legal frameworks (United Nations 2009). It is not totally possible to predict the future of urban and national development strategies because of diverse unknown factors and variables that come into play. Surely, the understanding of informal settlements and its improvement by adopting regularization processes, which put more focus on climate vulnerability and stakeholders' participation, may help to formulate strategies for the future sustainable urban land management. However, if the present trends continue, the informal settlements will remain a red spot on the city map and will challenge the resilience urban future of Khulna. Last but not the least, in the era of climate change, migration from rural to urban areas is obviously not a sustainable option; besides, the whole urban community will be at risk. Therefore, it is necessary to find out innovative mechanisms of socio-spatial planning in the context of Bangladesh with comprehensive livelihood risk analysis especially for the suburban rural areas.

\section{References}

ALAM M. A., AKTER S. (2012), Slum eviction in Bangladesh: Seeking solutions, The Daily Star 266, Dhaka.

ANGELES G., LANCE P., BARDEN-O'Fallon J., ISLAM N., MAHBUB A. Q. M., NAZEM N. I. (2009), The 2005 census and mapping of slums in Bangladesh: design, select results and application, International Journal of Health Geographics 8 (32), 1-19.

AYLETT A. (2014), Progress and Challenges in the Urban Governance of Climate Change: Results of a Global Survey, MIT, Cambridge.

BEGUM H., MOINUDDIN G. (2010), Spatial Dimension of Social Exclusion. An Imperial Investigation into the Relationship of Housing and Social Exclusion in the Slums of Dhaka City, Management Research and Practice 2 (3), 314-328.

BOSHER L., PENNING-ROWSELL E., TAPSELL S. (2007), Resource Accessibility and Vulnerability in Andhra Pradesh: Caste and Non-Caste Influences, Development and Change 38 (4), 615-640. 
BROOKS N. (2003), Vulnerability, risk and adaptation: A conceptual framework, Tyndall Centre for Climate Change Research Working Paper 38.

CLACC (2009), Climate change and the urban poor. Risk and resilience in 15 of the world's most vulnerable cities, IIED, London.

COHEN B. (2004), Urban Growth in Developing Countries: A Review of Current Trends and a Caution Regarding Existing Forecasts, World Development 32 (1), 23-51.

COMFORT L. K. (1999), Shared risk: Complex systems in seismic response, Emerald, Amsterdam/New York.

DODMAN D., SATTERTHWAITE D. (2008), Institutional capacity, Climate change adaptation and the Urban Poor, IDS Bulletin 39 (4), 67-74.

DURAND-LASSERVE A. (1996), Regularization and Integration of Irregular Settlements: Lessons From Experience, UNDP Working Paper No. 6, Nairobi.

ENEMARK S., MCLAREN R. (2008), Preventing Informal Development - through means of sustainable land use control, FIG Working Week - Integrating Generations Proceedings, $1-18$.

FEIDEN P. (2011), Adapting to Climate Change: Cities and the Urban Poor, International Housing Coalition, Washington, DC.

HARDOY J. E., MITLIN D., SATTERTHWAITE D. (2001), Environmental Problems in an Urbanizing World, Earthscan, London.

IPCC (2008), Climate change 2007: Synthesis report, IPCC, Geneva.

JABEEN H., JOHNSON C., ALLEN A. (2010), Built-in resilience: learning from grassroots coping strategies for climate variability, Environment and Urbanisation 22 (2), 415-431.

LAUKKONEN J., BLANCO P. K., LENHART J., KEINER M., CAVRIC B., KINUTHIANJENGA C. (2009), Combining climate change adaptation and mitigation measures at the local level, Habitat International 33 (3), 287-292.

MALLICK B., RAHAMAN K. R., VOGT J. (2011), Social vulnerability analysis for sustainable disaster mitigation planning in coastal Bangladesh, Disaster Prevention and Management: an International Journal 20 (3), 220-237.

MASUM F. (2009), Urban Fringe Management and Role of Good Governance: Integrating Stakeholders in Land Management Process, $7^{\text {th }}$ FIG Regional Conference Proceedings, $1-11$.

MORRIS J., BADDACHE F. (2012), Back to basics: how to make stakeholder engagement meaningful for your company, Business for Social Responsibility, New York/Paris.

MURTAZA M. G. (2000), Slum Improvement Scheme in Khulna City - A Review, Khulna University Studies 2 (1), 239-244.

OLIVER-SMITH A. (2009), Sea Level Rise and the Vulnerability of Coastal Peoples: Responding to the Local Challenges of Global Climate Change in the $21^{\text {st }}$ Century, UNU-EHS, Bonn.

PATEL K. (2013), A successful slum upgrade in Durban: A case of formal change and informal continuity, Habitat International 40, 211-217.

RAVALION M. (2001), On the urbanization of poverty, Journal of Development Economics 68, 435-442.

RENAUD F. G. (2012), Environmental components of vulnerability, in: Birkmann J. (ed.), Measuring Vulnerability to Natural Hazards: towards disaster resilient societies, United Nations University Press, Tokyo, pp. 117-127.

RESILIENCE ALLIANCE (2007), Urban Resilience Research Prospectus, Resilience Alliance, Canberra.

REVELL K. (2010), Working with Informality, $46^{\text {th }}$ ISOCARP Congress Papers, 1-13. ROCKEFELLER FOUNDATION (2014), Building Climate Change Resilience in Cities, The Rockefeller Foundation, New York.

ROY G. S., ABDULLAH A. Q. M. (2005), Assessing Needs and Scopes of Upgrading

Urban Squatters in Bangladesh, BRAC University Journal 2 (1), 33-41.

ROY S., SOWGAT T. (2005), People's participation: Planning Practice in a third world 
city. the Case of Khulna City, CABERNET, London.

SATTERTHWAITE D., HUQ S., PELLING M., REID H., LANKAO P. R. (2007), Adapting to climate change in urban areas: the possibilities and constraints in low- and middle-income nations, IIED, London.

SIDDIQUE Q. I., ALAM A. B. M. A., RAHMAN M., RAHMAN A., JAHAN H. (2002), Slum Improvement Project in Dhaka Metropolitan City, World Urban Economic Development, 96-107. SMIT B., BURTON I., KLEIN R. J. T., WANDEL J. (2000), An anatomy of adaptation to climate change and variability, Climate Change 45, 223-251.

TANNER T., MITCHELL T., POLACK E., GUETENTER B. (2009), Urban Governance for Adaptation: Assessing Climate Change Resilience in Ten Asian Cities, IDS Working Papers, 315, 1-47.

UN-HABITAT (2003), The Challenges of Urban Slums - Global Report on Human Settlements, UN-HABITAT, London and Sterling.

United Nations (2009), Self-made cities: in Search of sustainable solutions for informal settlements in the United Nations Economic Commission for Europe region, United Nations, New York/Geneva.

VALKERING P., ROTMANS J., KRYWKOW J., VAN DER VEEN A. (2005), Simulating stakeholder support in a policy process: an application to river management, Simulation 81 (10), 701-708.

VINCENT O. O. (2009), Exploring spatial growth pattern of informal settlements through agent-based simulation, $\mathrm{PhD}$ Thesis, Utrecht University, Utrecht.

WARNER K. (2010), Assessing Institutional and Governance Needs Related to Environmental Change and Human Migration, Climate Change and Migration, 1-19.

WARNER K., EHRHART C., SHERBININ A., ADAMO S. (2009), In search of Shelter: Mapping the effects of climate change on human migration and displacement, CARE, Bonn. WORLD BANK (2010), Cities and climate change: an ergent agenda, The World Bank, Washington, DC.

Initial submission: 14.03 .2015

Revised submission: 31.05 .2015

Final acceptance: 17.06 .2015

Correspondence: Department of Urban Planning and Land Management, Institute of Geodesy and Geo-information, University of Bonn, Nußallee 17 D-53115, Bonn, Germany

E-mail: sujit.sikder@uni-bonn.de 
